Biogeosciences, 10, 3793-3807, 2013

www.biogeosciences.net/10/3793/2013/

doi:10.5194/bg-10-3793-2013

(C) Author(s) 2013. CC Attribution 3.0 License.

\title{
Mercury dynamics in the Rocky Mountain, Colorado, snowpack
}

\author{
X. Faïn ${ }^{1,3}$, D. Helmig ${ }^{2}$, J. Hueber ${ }^{2}$, D. Obrist ${ }^{3}$, and M. W. Williams ${ }^{2}$ \\ ${ }^{1}$ UJF - Grenoble 1 / CNRS, Laboratoire de Glaciologie et Géophysique de l'Environnement (LGGE) UMR 5183, \\ Grenoble 38041, France \\ ${ }^{2}$ Institute of Alpine and Arctic Research, University of Colorado at Boulder, Boulder, Colorado, USA \\ ${ }^{3}$ Desert Research Institute, Division of Atmospheric Sciences, 2215 Raggio Parkway, Reno, Nevada 89512, USA \\ Correspondence to: D. Helmig (detlev.helmig@Colorado.edu)
}

Received: 5 September 2012 - Published in Biogeosciences Discuss.: 2 November 2012

Revised: 29 March 2013 - Accepted: 17 April 2013 - Published: 13 June 2013

\begin{abstract}
Gaseous elemental mercury (GEM) was monitored at the Niwot Ridge (NWT) Long-Term Ecological Research (LTER) site (Colorado, USA, $40^{\circ} \mathrm{N}$ ) from interstitial air extracted from the snowpack at depths ranging from the snow surface to $10 \mathrm{~cm}$ above the soil. A highly dynamic cycling of mercury $(\mathrm{Hg})$ in this mid-latitude snowpack was observed. Patterns were driven by both GEM production in surface snow and GEM destruction in the deeper snowpack layers. Thorough mixing and vertical transport processes were observed through the snowpack. GEM was photochemically produced near the snow-air interface throughout the entire winter, leading to enhanced GEM levels in interstitial air of surface snow of up to $8 \mathrm{ng} \mathrm{m}^{-3}$. During low-wind periods, GEM in surface snow layers remained significantly above ambient air levels at night as well, which may indicate a potential weak GEM production overnight. Analyses of vertical GEM gradients in the snowpack show that surface GEM enhancements efficiently propagated down the snowpack, with a temporal lag in peak GEM levels observed with increasing depth. Downward diffusion was responsible for much of these patterns, although vertical advection also contributed to vertical redistribution. Destruction of GEM in the lower snowpack layers was attributed to dark oxidation of GEM. Analysis of vertical GEM $/ \mathrm{CO}_{2}$ flux ratios indicated that this GEM destruction occurred in the snow and not in the underlying soil. The strong, diurnal patterns of photochemical GEM production at the surface ultimately lead to re-emission losses of deposited $\mathrm{Hg}$ back to the atmosphere. The NWT data show that highest GEM surface production and re-emissions occur shortly after fresh snowfall, which possibly resupplies photoreducible $\mathrm{Hg}$ to the snowpack, and that photochemical GEM reduction is not radiation-limited as it is strong even on cloudy days.
\end{abstract}

\section{Introduction}

Various natural and anthropogenic sources emit mercury $(\mathrm{Hg})$ to the atmosphere, either as gaseous elemental $\mathrm{Hg}$ $\left(\mathrm{GEM}, \mathrm{Hg}^{\circ}\right.$ ) or as reactive, divalent $\mathrm{Hg}$ species ( $\left.\mathrm{Hg}(\mathrm{II})\right)$. Due to its long lifetime, GEM can be transported over long distances in the atmosphere (Selin et al., 2007). Atmospheric GEM can directly deposit to surfaces (Zhang et al., 2009, and references therein), or it can undergo chemical reactions and subsequently deposit as divalent $\mathrm{Hg}$ (II) (Schroeder and Munthe, 1998). Deposition of atmospheric $\mathrm{Hg}$ is the main source of $\mathrm{Hg}$ contamination in remote terrestrial ecosystems (e.g., Fitzgerald et al., 1998; Fisher et al., 2012). Deposited $\mathrm{Hg}$ may also revolatilize back to the atmosphere as GEM from both land (Ericksen et al., 2005) and water surfaces (Kuss et al., 2011). The global biogeochemical cycle of $\mathrm{Hg}$ is hence highly complex and involves multiple exchange processes between natural reservoirs (such as soils, snow and ice, and water) and the atmosphere (Lindberg et al., 2007).

Among natural $\mathrm{Hg}$ reservoirs, the role of the cryosphere (i.e., snow- and ice-covered surfaces) is important as it represents a highly dynamic system situated between the atmosphere and the subniveal (covered by the snowpack) ecosystems (Dominé and Shepson, 2002). A recent review from Durnford and Dastoor (2011) concluded that no study has yet simulated the behavior of $\mathrm{Hg}$ in the cryosphere near its full complexity, and that it is crucial to develop models based on physical and chemical processes to simulate revolatilization processes from the cryosphere, particularly in regards to future changes in climate. Snowpacks act as $\mathrm{Hg}$ reservoirs for atmospheric $\mathrm{Hg}$, but an important fraction of $\mathrm{Hg}$ that is deposited onto snow surfaces also is readily emitted back to the atmosphere (Steffen et al., 2002; Dommergue et al., 2003a; Sommar et al., 2007; Johnson et al., 2008; Faïn et al., 2011). 
This snowpack chemistry is important as seasonal snowpacks are often considered a pollution source for ecosystems because meltwater contains considerable amounts of atmospheric pollutants, including $\mathrm{Hg}$. Further, $\mathrm{Hg}$ that enters the meltwater may be converted to highly toxic methylmercury that is subject to bioaccumulation through the aquatic food chain (Lockhart and Evans, 2000; Douglas et al., 2012). It is hence important to understand the physical and chemical processes that control the ultimate fate of $\mathrm{Hg}$ in snowpacks.

While some of the $\mathrm{Hg}$ deposited onto the snowpack is rapidly re-emitted (Durnford and Dastoor, 2011), quantification of the precise fractions revolatilized is still hotly debated. For example in the Arctic, some studies have suggested that net deposition associated with springtime atmospheric mercury depletion events (AMDEs; see Steffen et al., 2008 , for a review) is low or insignificant because of strong re-emission processes (St Louis et al., 2005; Kirk et al., 2006; St Louis et al., 2007; Hedgecock et al., 2008) and that there is no firm evidence that AMDEs exert a significant influence on $\mathrm{Hg}$ concentrations in the Arctic Ocean (Outridge et al., 2008). However, other studies have concluded that AMDEs lead to net annual losses of atmospheric GEM (Steffen et al., 2005) and that a substantial fraction of deposited Hg accumulates in snow (Hirdman et al., 2009). While many studies investigating the behavior of $\mathrm{Hg}$ in snowpacks have focused on polar latitudes, snow $\mathrm{Hg}$ dynamics in mid-latitude snowpacks are also important, particularly as they are generally closer to sources of $\mathrm{Hg}$ emissions and areas of high population density. Further, different environmental conditions in temperate latitude snowpacks are expected to impact the behavior of snow $\mathrm{Hg}$ - such as, for example, effects of forest canopies and subniveal soil (Poulain et al., 2007; Nelson et al., 2008). Consequently, results from polar studies may not be directly applicable to mid-latitude snowpacks.

We conducted extensive $\mathrm{Hg}$ sampling in a temperatelatitude snowpack and the lower atmosphere at Niwot Ridge (NWT), a Long-Term Ecological Research (LTER) site located in the Rocky Mountains, Colorado, USA. We continuously sampled GEM, ozone, and $\mathrm{CO}_{2}$ at six different depths in the seasonal snowpack plus in the atmosphere using a fully automated, continuous snow-gradient sampling system. In addition, physical properties of the snowpack (e.g., density and temperature), meteorological data, and total $\mathrm{Hg}$ content of two snow pits excavated in our study were investigated. The main goals of this study were to improve our understanding of $\mathrm{Hg}(\mathrm{II}) / \mathrm{GEM}$ redox conversions within the snowpack and to assess how such conversions ultimately affect $\mathrm{Hg}$ loads of alpine snowpacks during snowpack accumulation and snowmelt.

\section{Methods}

\subsection{Study site}

This experiment was conducted from 2 February to 5 May 2009 in a forest clearing near tree line at the high-elevation Soddie site at the NWT-LTER $\left(40^{\circ} 03 \mathrm{~N}\right.$, $105^{\circ} 35,3340 \mathrm{~m}$ a.s.l). The site has a $10^{\circ}$ southwest-facing slope (Erickson, 2004) and has an underground laboratory $(3 \mathrm{~m} \times 9 \mathrm{~m} \times 2.4 \mathrm{~m})$ with available line power. An adjacent tower (10 $\mathrm{m}$ away) is equipped with a suite of meteorological instruments. Snow cover at the Soddie site generally lasts from late October into June, and $\sim 80 \%$ of the annual precipitation of $\sim 1000 \mathrm{~mm}$ falls as snow (Caine, 1995). During the sampling period, the snowpack thickness at the Soddie site varied from $138 \mathrm{~cm}$ to $184 \mathrm{~cm}$. We observed only 4 precipitation events with daily accumulation larger than $10 \mathrm{~cm}$ of snow (day of year (DOY) 86, 94, 108, and 123). The precipitation which occurred on DOY 108 deposited about $75 \mathrm{~cm}$ of fresh snow at the Soddie site; however the GEM measurements were not running during this period.

\subsection{Snowpack gradient sampling method}

Snowpack gas flux research at the Soddie site was initiated in the winter of 2003/2004. Since then, snowpack studies have been conducted at this site every year (Williams et al., 2009). Seok et al. (2009) provide an extensive description of the snowpack gradient tower (including photographs and diagrams) that is installed for measurements of snow interstitial air (SIA) trace gas concentrations. This same manifold was used during this study for continuous sampling of GEM, ozone and $\mathrm{CO}_{2}$ in the SIA and the atmosphere. This multilevel gradient tower is constructed of square aluminum alloy tubing, has $60 \mathrm{~cm}$ long cross bars at seven heights above the ground $(10,30,60,90,120,150$, and $245 \mathrm{~cm})$, and was installed at the Soddie site before the onset of the snow accumulation season. The system becomes progressively covered by precipitating snow and thereby facilitates in situ snowpack gas measurements throughout the snow-covered season without disturbances. The $245 \mathrm{~cm}$ inlet remained above the maximum snowpack height during the entire sampling period and air collected from this height thus represents ambient atmospheric concentrations. Each of the seven cross bars supported a pair of sampling inlets, fitted with $25 \mathrm{~mm}$ Acrodisc ${ }^{\circledR}$ hydrophobic polytetrafluoroethylene (PTFE) syringe filters (Pall Life Sciences, Ann Arbor, Michigan, USA) to prevent particles from entering the sampling lines. Sampling lines were all made of perfluoroalkoxy (PFA) Teflon ${ }^{\circledR}$, inner diameter of $3.9 \mathrm{~mm}$ and outer diameter of $6.4 \mathrm{~mm}$ (Parker Hannifin, Cleveland, Ohio, USA), with equal lengths of $18 \mathrm{~m}$. All sampling lines were directed to the underground laboratory, which housed the analytical instruments. Sections of the sampling lines outside the laboratory were wrapped in pipe insulation with a self-controlling water pipe heater to 
maintain line temperatures slightly above $0^{\circ} \mathrm{C}$ to prevent water from freezing and clogging sampling lines. The selection of inlets for sampling at a particular height was done through an array of seven solenoid valves.

Sampling was conducted by drawing air sequentially from the $245 \mathrm{~cm}$ height inlet to the $10 \mathrm{~cm}$ height inlet for $10 \mathrm{~min}$ each. Air from the snow inlets at a total sampling rate of $2.51 \mathrm{~min}^{-1}$ was directed to GEM, ozone, and $\mathrm{CO}_{2}$ analyzers; since the sampling flow was split between two paired inlets at each height, the effective sampling rate per inlet line was $1.251 \mathrm{~min}^{-1}$. The sampling manifold, calibration system, and data acquisition were controlled through an array of digital input/output modules, temperature input components, and LabVIEW software (National Instruments, Austin, Texas, USA).

GEM was determined using a Tekran 2537B vapor phase mercury analyzer. The 2537B instrument collects the air stream on two gold cartridges. GEM is thermally desorbed and detected by cold vapor atomic fluorescence spectrometry at $253.7 \mathrm{~nm}$. Use of dual gold cartridges allows alternate sampling and desorption on two separate sampling traps, resulting in a continuous measurement of GEM. We sampled GEM at $2.5 \mathrm{~min}$ time resolution, resulting in four GEM data points per sampling depth interval. To avoid possible artifact related to the transition from one inlet to the next, the first measurement collected at each inlet was excluded, and the two subsequent measurements were averaged to calculate a mean concentration for each $10 \mathrm{~min}$ interval. A mass flow meter supplies the 2537B with a sample volume referenced to STP (Standard Temperature and Pressure: $0{ }^{\circ} \mathrm{C}$, $1 \mathrm{~atm})$. Set-up, accuracy, and precision of this instrument have been evaluated previously during field comparisons at an urban/industrial site (Ebinghaus et al., 1999) and a remote marine background location (Schroeder et al., 1995). The analyzer was recalibrated every 25 -h using its internal permeation source. Blanks were measured during each internal calibration cycle and were consistently $<0.01 \mathrm{ng} \mathrm{m}^{-3}$.

$\mathrm{CO}_{2}$ mixing ratios were determined with an infrared gas analyzer (IRGA, LI-COR LI-7000, Lincoln, NE, USA). $\mathrm{CO}_{2}$ mixing ratios in the snowpack reached beyond the factorycalibrated range of 0-3000 ppm for the LI-7000 instrument. As a result, calibrations above $3000 \mathrm{ppm}$ were necessary and conducted using a $1 \% \mathrm{CO}_{2}$ standard that was diluted with zero air using a dynamical dilution system. Daily single point $\mathrm{CO}_{2}$ calibrations ( $450 \mathrm{ppm}$ ) were performed to monitor the drift of the instrument $(<1 \%$ drift over entire sampling period). Ozone was monitored using a UV absorption analyzer (Model 49, Thermoenvironmental Corp.). Snow air was analyzed for ozone and $\mathrm{CO}_{2}$ every $10 \mathrm{~s}$ and averaged for the respective $5 \mathrm{~min}$ interval corresponding to GEM measurements.

\subsection{Ancillary data}

Temperatures at each sampling height were measured using type-E thermocouple wires (Omega Engineering, Inc., Stamford, Connecticut, USA) that were covered by white heat shrink tubing to reduce radiation artifacts. Wind speed, at $6 \mathrm{~m}$ above the ground on the meteorological (MET) tower $10 \mathrm{~m}$ away, was measured using a 05103-L R.M. Young Wind Monitor (Campbell Scientific, Logan, Utah, USA). Barometric pressure was measured using a CS105 Vaisala PTB101B Barometer (Campbell Scientific, Logan, Utah, USA), and incoming solar radiation data (spectral range of 305-2200 nm) were collected with an NR-Lite (Kipp and Zonen) sensor.

Readings of snow depth were taken at 1-2-week intervals from calibrated marks on the snow tower. Gaps in the snow depth record were filled by comparing and interpolating the daily snow depth record from the Niwot SNOTEL site, $1.5 \mathrm{~km}$ from the Soddie site. An analysis of the linear correlation between concurrent snow depth data from these two sites resulted in a coefficient of determination, $r^{2}$, of 0.83 .

\subsection{Snow sampling and total $\mathrm{Hg}$ analysis}

Two snowpack profiles were sampled and analyzed for total $\mathrm{Hg}$ (THg, no filtering) in an open, undisturbed area in close vicinity of the Soddie lab. These sampling sites showed similar characteristics, for example in regards to daytime sun exposure and distance from the trees. Snowpits were sampled on 9 March and 27 April 2009 for depth profiles of THg in depth intervals of $25 \mathrm{~cm}$ from the surface to the underlying ground. We used $250 \mathrm{ml}$ borosilicate glass bottles previously cleaned at the Desert Research Institute using 5\% $\mathrm{HNO}_{3}$ acid bath and ultrapure water rinsing $(18.2 \mathrm{M} \Omega \mathrm{cm})$ for snow sampling. All snow samples were collected using clean snow sampling procedures; samples were immediately stored in the dark at $-20^{\circ} \mathrm{C}$ until analysis.

Snow samples were analyzed for total $\mathrm{Hg}$ (THg, no filtering) using a Tekran Model 2600 analyzer (Tekran Inc., Toronto, Canada) according to US EPA method 1631 revision E. Briefly, samples were oxidized with $0.5 \% \mathrm{v} / \mathrm{v} \mathrm{BrCl}$ $24 \mathrm{~h}$ before analysis to digest $\mathrm{Hg}$ bound to complexes. Excess $\mathrm{BrCl}$ was neutralized with pre-purified hydroxylamine hydrochloride. Samples were then automatically mixed with $\mathrm{SnCl}_{2}$ in a reaction vessel to reduce $\mathrm{Hg}$ (II) to GEM. A phase separator and Argon gas were used to load GEM onto two sequential gold traps. After thermal desorption, GEM was detected by atomic fluorescence spectrometry. The Tekran Model 2600 was calibrated every day with the NIST SRM-3133 Hg standard (curves with standards of $0,0.5$, 1, 5, 10, 25, and $50 \mathrm{ng} \mathrm{l}^{-1} \mathrm{Hg}$ ). The detection limit (DL) was re-evaluated every analytical run on a limited set of blanks (usually 3 , DL averaging $0.2 \mathrm{ng}^{-1}$ ). During analyses, ongoing precision recovery (OPR; $5 \mathrm{ngl}^{-1}$ ) was periodically analyzed to check the stability of the system; these 


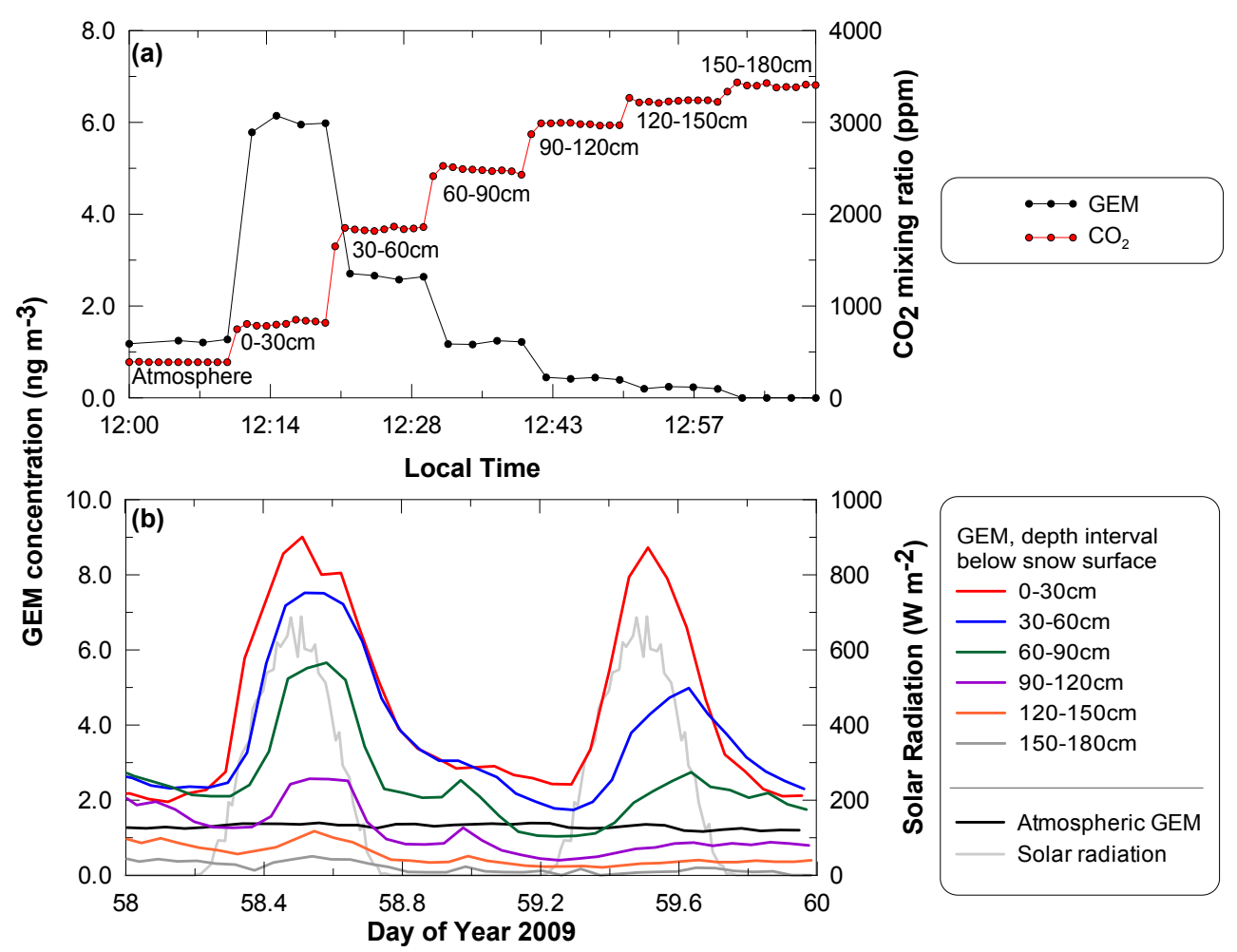

Fig. 1. (a) Time series of GEM and $\mathrm{CO}_{2}$ mixing ratios during one sampling cycle from the snowpack gradient sampling tower on 1 March 2009. This 70 min sampling started with 10 min of measurements in ambient air above the snow, and then moved downward in 10 min intervals towards the bottom of the snowpack (six measurement heights in the snow). Total snowpack depth at this time was $162 \mathrm{~cm}$. (b) GEM concentrations collected at the six levels in the snowpack and in the atmosphere above the snow (black line) from 27 to 28 February 2009. Snow height was $155 \mathrm{~cm}$ during this period. The gray line shows the diurnal solar irradiation cycle $\left(\mathrm{Wm}^{-2}\right)$.

measurements showed between $90-118 \%$ recovery. Reagent blanks were measured regularly to assure that the system was clean of contamination. All samples were analyzed in triplicate. THg concentrations reported in this paper are presented as means \pm 1 standard deviations. Four field blanks were collected and analyzed, resulting in $0.1 \pm 0.1 \mathrm{ng} \mathrm{l}^{-1}$ concentrations.

\section{Results and discussion}

\subsection{Vertical and temporal patterns of GEM in the snowpack and the atmosphere}

An example of time series data for GEM and $\mathrm{CO}_{2}$ collected on 1 March from 0:00 to 13:00 LT is illustrated in Fig. 1a. These data show one full sampling cycle through the seven inlets, with measurements starting above the snow surface (sampling height $245 \mathrm{~cm}$, i.e., $83 \mathrm{~cm}$ above the snow surface at this time). All GEM data collected in SIA and discussed in this study were combined to evenly spaced $30 \mathrm{~cm}$ depth intervals down from the top of the snowpack; e.g., the $0-30 \mathrm{~cm}$ layer contains data when inlets were sampling at that depth range; in the same way we summarized all other depth layers.
This representation of data is different from previous publications resulting from the NWT snow tower (Williams et al., 2009, and references therein) but is appropriate for GEM, a reactive gas experiencing fast production processes in the upper layer of the snowpack (see below).

The GEM concentration in the ambient air above the snowpack (i.e., the $245 \mathrm{~cm}$ inlet) shown in Fig. 1a is $1.2 \mathrm{ng} \mathrm{m}^{-3}$, GEM levels increased in the upper layer of the snowpack $(0-30 \mathrm{~cm}$ depth the snow surface), and GEM levels then decreased steadily as the sampling sequence progressed downwards into the snowpack. Corresponding $\mathrm{CO}_{2}$ mixing ratios were approximately $389 \mathrm{ppm}$ in ambient air, which then increased with depth to peak mixing ratios of $3390 \mathrm{ppm}$ in the lowest snowpack layer (i.e., $150-180 \mathrm{~cm}$ depth). This example demonstrates the performance and reliability of the measurements; for example, the $\mathrm{CO}_{2}$ mixing ratio gradient follows patterns that have been well characterized for this alpine snowpack (Liptzin et al., 2009, and references therein); very similar GEM and $\mathrm{CO}_{2}$ snowpack profiles were seen during the 2011-2012 winter season where similar measurements were conducted. Please also note that both ambient levels of GEM and $\mathrm{CO}_{2}$ are close to the global 


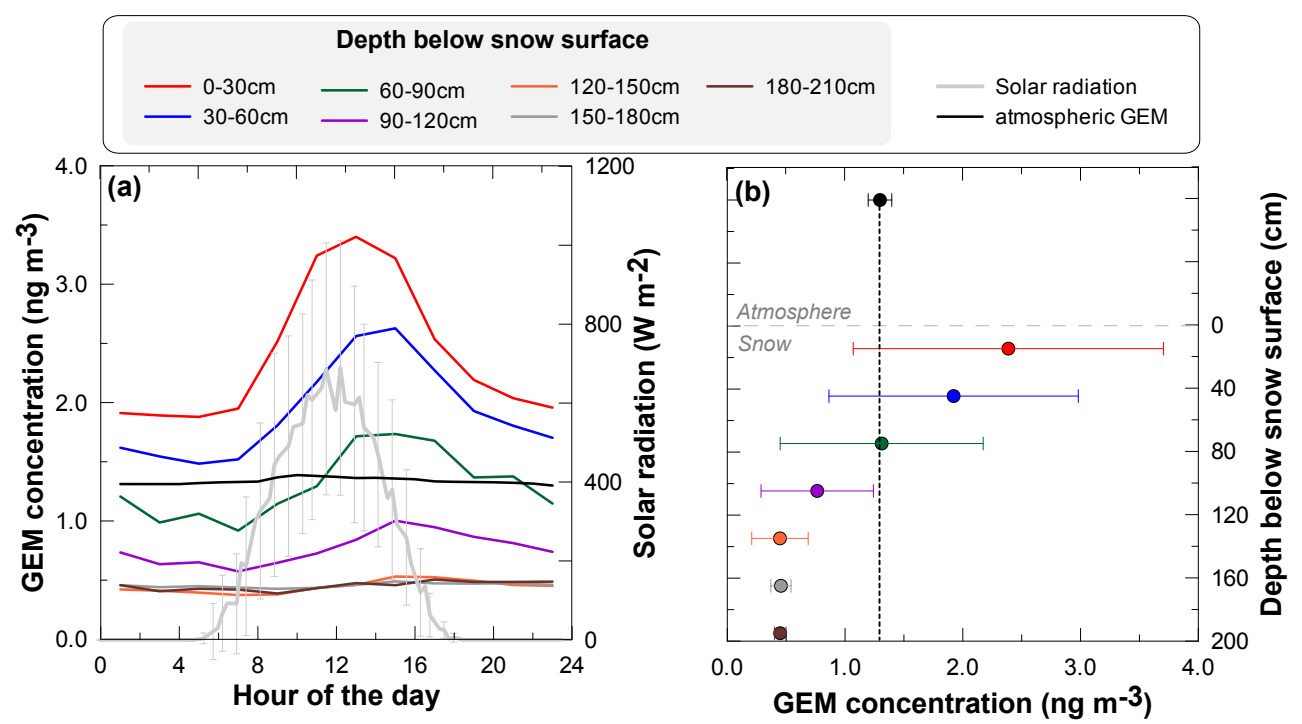

Fig. 2. Snow air GEM data from DOY 37 to 122, 2009, combined into $30 \mathrm{~cm}$ depth intervals down from the top of the snowpack. (a) Diurnal evolution and averaged incoming solar radiation in the depth profile. (b) Averaged vertical patterns and standard deviation for the respective depth layers. The dashed vertical line shows the mean ambient atmospheric GEM concentration.

ambient background, highlighting that measurements were not subjected to leaks or contamination.

The data from air withdrawn from the snowpack show both concentration enhancements and depletion of GEM compared to ambient air levels during this 70 min sampling cycle. GEM enhancements as high as $6 \mathrm{ng} \mathrm{m}^{-3}$, or equivalent to approximately five times ambient air levels, must reflect a source or production of GEM in the snowpack. Similarly, lower-than-ambient GEM levels in deeper snowpack with levels near the snow-soil interface during this day completely depleted in GEM (i.e., GEM below D.L.) must be due to removal or destruction of GEM.

In Fig. 1b, we show the time series of GEM concentrations at six levels in the snow and in the atmosphere above the snow surface from 27 to 28 February 2009 , a period exemplary of the study and exhibiting low wind speed. Snowpack height during this period was $154 \mathrm{~cm}$, and consequently all six inlets except the ambient air inlet at $245 \mathrm{~cm}$ (black line) reflect SIA GEM levels. During this time period atmospheric GEM remained relatively stable at $\sim 1.2 \mathrm{ng} \mathrm{m}^{-3}$. Pronounced enhancements of GEM concentrations were observed within the top $60 \mathrm{~cm}$ of the snowpack, and these exhibited strong diel cycles. Diel cycles of GEM enhancements coincide well with the solar irradiation cycle (gray line in Fig. 1b), with maximum GEM enhancements observed at midday. Deeper in the snowpack, particularly close to the soil-snow interface, GEM was always depleted compared to atmospheric values and showed little temporal variability. Figure $1 \mathrm{~b}$ confirms the depth profile of GEM shown in Fig. 1a, but demonstrates that GEM enhancement near the snow-air interface exhibit strong temporal patterns. GEM concentrations deeper in the snowpack show much smaller temporal variability compared to upper snowpack levels, and these might be related to diffusion from above snow layers (see below).

The GEM patterns in snow interstitial air described in Fig. 1 persisted through the entire measurement campaign. Figure 2 shows a summary of all available GEM data collected between 2 February and 5 May 2009 (i.e., marked DOY 37 to DOY 122), averaged by hour of the day (Fig. 2a) and by snow depth intervals ( $30 \mathrm{~cm}$ intervals, Fig. $2 \mathrm{~b}$ ).

Figure 2 illustrates that atmospheric GEM concentrations showed little variation during this winter-spring sampling season $\left(1.3 \pm 0.1 \mathrm{ng} \mathrm{m}^{-3}\right.$; mean \pm stdev $)$. Height of the atmospheric sampling inlet above the snowpack varied during the measurement period from $110 \mathrm{~cm}$ to $50 \mathrm{~cm}$ (respectively, maximum and minimum heights observed); however, such changes did not impact the measured atmospheric GEM concentrations. The ambient GEM levels are in the lower range of values reported from 22 rural sites in the Northern Hemisphere (i.e., $1.7 \pm 0.3 \mathrm{ng} \mathrm{m}^{-3}$ ) (Valente et al., 2007), and also lower than the value of $1.6 \pm 0.2 \mathrm{ng} \mathrm{m}^{-3}$ (mean atmospheric total gaseous $\mathrm{Hg}$ ) collected from 11 sites of the Canadian Atmospheric Mercury Network (CAMNet) between 1995 and 2005 (Temme et al., 2007). Simultaneous GEM measurements in the Sierra Nevada mountains at 1920 m a.s.l. (Sagehen Station, CA) during spring 2009 showed GEM levels of $1.4 \pm 0.2 \mathrm{ng} \mathrm{m}^{-3}$ (Faïn et al., 2011), and GEM concentrations observed at the close-by Storm Peak Laboratory in the Rocky Mountains (3200 m a.s.l., CO) during spring of 2008 averaged $1.6 \pm 0.3 \mathrm{ng} \mathrm{m}^{-3}$ (Faï et al., 2009). This comparison illustrates the remote and clean-air characteristics of the Niwot Ridge research site. 


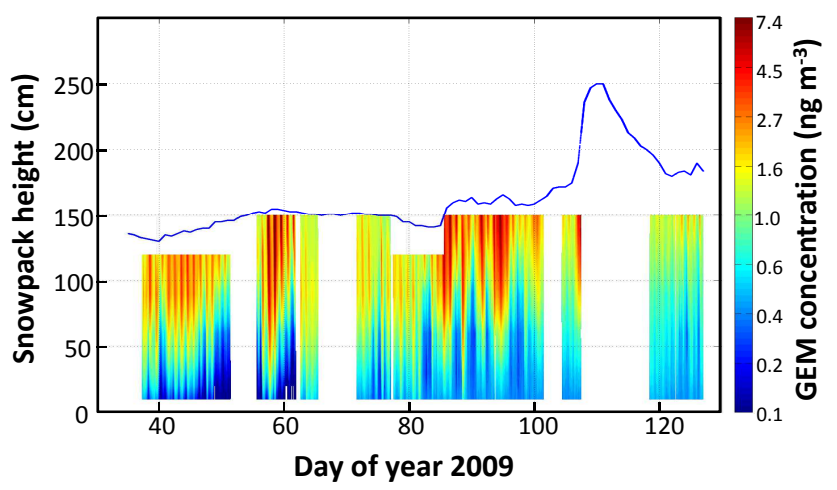

Fig. 3. Color contour plot of GEM in the snowpack. The upper edge (blue line) of the colored area indicates the snowpack height, the $\mathrm{x}$-axis, the day of year 2009, and the color log scale shows the concentration of GEM.

Figure 2a confirms the pronounced diel concentration cycles of GEM in the snow air in the uppermost snowpack layers. The lowest two snowpack layers, on the other hand, showed little diurnal fluctuation in GEM concentrations. These patterns are also reflected in Fig. $2 b$ by the largest variability of GEM measured in the top snow layers. The most pronounced diurnal cycle, as well as overall highest GEM enhancement, was observed in the top snowpack layer, where GEM concentrations peaked at 13:00. While diurnal patterns of GEM followed a similar diurnal pattern of solar radiation (Fig. 2a), the peak of GEM enhancements was slightly shifted in regards to maximum solar radiation; peak solar radiation occurred at $\sim 12: 00$, while peak GEM levels in the top 0-30 $\mathrm{cm}$ occurred around 13:00. The diurnal GEM peak was further delayed deeper in the snowpack; e.g., in the layer 30-60 $\mathrm{cm}$ below the surface GEM peaked at $\sim$ 15:00. These patterns suggest that interstitial air transport processes, which redistribute GEM from the upper snow levels towards deeper snow layers, are involved in determining these patterns (see below).

The general features shown in Fig. 2 are summarized below, and underlying reasons are discussed in detail in Sects. 3.2 and 3.3. First, from the surface snow to $60 \mathrm{~cm}$ depth, GEM in snow interstitial air was consistently enhanced compared to atmospheric levels, both during nights and days. The data from the $60-90 \mathrm{~cm}$ depth interval showed a transition where GEM was higher during midday and lower during nights compared to atmospheric values. Below $90 \mathrm{~cm}$ depth, we observed that GEM concentrations were consistently below those found in ambient air, independent of daytime or nighttime. At the lowest levels (from $120 \mathrm{~cm}$ depth to the snow-soil interface), GEM was found to be rather constant $\left(\sim 0.4 \mathrm{ng} \mathrm{m}^{-3}\right)$ during almost the entire campaign, except during two events (DOY 49-51 and DOY 60-63) when GEM concentration dropped below the instrument detection limit at this depth.
In Fig. 3, all data measured during the 2009 experiment within the snowpack (about 18 daily measurements at each level) are combined in a color contour graph to show in detail the spatial and temporal evolution of GEM in the snowpack. Continuous vertical patterns were obtained by linear interpolation of GEM levels measured at successive inlets. Due to changing snowpack height (shown as blue line in the figure), the depth of the upper snowpack sampling inlet varied from only a few $\mathrm{cm}$ to almost $30 \mathrm{~cm}$ depth below the snow surface at times. During five periods (gaps in Fig. 3), GEM sampling was interrupted due to other experiments performed and instrument maintenance. This figure visualizes the GEM production in surface snow and the depletion of GEM in deeper snowpack. As shown in Fig. 2, strong diurnal concentration fluctuations can be observed (e.g., note from DOY 37 to 64).

The behavior of GEM in the snow air as revealed by Figs. 1 to 3 is likely driven by a combination of different processes, including (i) chemical or biological processes leading to destruction and/or production of GEM, (ii) GEM diffusion between snow layers, (iii) natural ventilation, and (iv) advective flow induced by the sampling procedure. While we discuss points (i) to (iii) in the sections below, Fig. 1 suggests that advective flow induced by the sampling procedure is likely too low to significantly impact measurements. GEM levels during consecutive 2.5 min measurements are stable (Fig. 1), including at the surface, indicating that advection of air from different depths or from the atmosphere was minor. Previous snowpack gas studies using this system showed similar results; i.e., there was no evidence of significant samplinginduced snowpack ventilation at a total rate of $3.21 \mathrm{~min}^{-1}$ for both nitrogen oxides $\left(\mathrm{NO}_{\mathrm{x}}\right)$ and $\mathrm{O}_{3}$ measurements (Helmig et al., 2009; Seok et al., 2009).

\subsection{GEM production in the upper snow layers}

In the upper snow layers GEM concentrations were always enhanced relative to levels in the atmosphere above, both during daytime and nighttime throughout the measurement campaign. Snow layers below the surface always exhibited higher GEM as compared to lower snow depths and to ambient air; it is therefore not possible that the enhanced GEM levels originated from diffusion or advection from either above or below. Consequently, the GEM concentration enhancements in the near-surface snow layers must be associated with in situ production of GEM in the surface snowpack. Depth patterns indicate that GEM production was strongest in the snow near the surface, that GEM production peaked slightly after midday, and that amplitudes of GEM fluctuations were dampened in deeper snow layers and further delayed in their timing. The delay of GEM diurnal maxima in the $30-60 \mathrm{~cm}$ and $60-90 \mathrm{~cm}$ depth layers suggests that transport plays a determining role in the GEM enhancement in these layers as this time lag would not be expected if in situ production was the main source of GEM in these layers. Active Hg-related photochemistry has been observed before to depths of $\sim 60 \mathrm{~cm}$ 
as well as limited to the top $\sim 3 \mathrm{~cm}$ depending on the investigated snowpack (Durnford and Dastoor, 2011, and references therein). We propose that GEM production at the NWT Soddie site mainly occurs in the $0-30 \mathrm{~cm}$ depth layer, and that the upper snowpack is the major source of GEM enhancements that were also observed in the deeper snowpack.

In situ production of GEM is attributed to photoreduction of $\mathrm{Hg}$ (II) to GEM, and has been reported to be facilitated by both visible (400-750 nm) (Poulain et al., 2004; Johnson et al., 2008) and UV-A radiation (320-400 nm) (Poulain et al., 2004; Faïn et al., 2007). Others suggest that photoreduction is enhanced by UV-B radiation $(280-320 \mathrm{~nm}$ ) (Poulain et al., 2004; Dommergue et al., 2007; Faïn et al., 2007), with $305-320 \mathrm{~nm}$ being the most important bandwidth (Dommergue et al., 2007). High UV loads at high-altitude sites, particularly in areas of low cloud cover such as in the Rocky Mountains, may particularly favor photochemical reduction of $\mathrm{Hg}(\mathrm{II})$. It has been suggested that photoreduction of oxidized $\mathrm{Hg}(\mathrm{II})$ in snow is driven by photo-dissociation of mercuric complexes (such as chlorocomplexes and hydroxocomplexes; Dommergue et al., 2003b), and that photoreduction may be promoted by reductants (Lalonde et al., 2002; Lalonde et al., 2003; Dommergue et al., 2007). Such possible reductants of oxidized $\mathrm{Hg}(\mathrm{II})$ are hydrogen peroxide $\left(\mathrm{H}_{2} \mathrm{O}_{2}\right)$ in pH-neutral snow (Lahoutifard et al., 2006), the hydroperoxyl radical $\left(\mathrm{HO}_{2}{ }^{\circ}\right)$ (Dommergue et al., 2003b; Dommergue et al., 2007), which also could be produced at night (Ferrari et al., 2004b), molecules related to humic acids (Dommergue et al., 2007), and sulphite-based compounds (Munthe et al., 1991; Van Loon et al., 2000). Laboratory investigations by Bartels-Rausch et al. (2011) showed that the presence of benzophenone and of oxalic acid significantly enhances the release of GEM from ice during irradiation, whereas humic acid is less potent to promote the reduction.

Importantly, mean GEM levels in the top layers of the NWT snowpack remained enhanced above atmospheric background throughout the night (Fig. 2a). Most laboratory and flux chamber experiments (Lalonde et al., 2003; Dommergue et al., 2007) and observations of GEM within snowpacks (Dommergue et al., 2003b; Poulain et al., 2004; St Louis et al., 2005) indicate that the presence of solar radiation is required for photoreduction and evolution of GEM. Two hypotheses could be considered to explain the Niwot Ridge data: (i) enhanced nighttime GEM levels could arise from retention of GEM in the snowpack that was formed during the day, or (ii) reduction of $\mathrm{Hg}$ (II) may also be possible in the dark. This production could be from a continuation of photolytically initiated reactions, i.e., be initiated by a UV-B pulse and continue in the dark for a certain time (Lalonde et al., 2003), or through a reaction requiring no photochemical initialization at all (Ferrari et al., 2004b). Numerical simulations of our data using Fick's second law of diffusion (see Sect. 3.3, using various values for tortuosity and porosity) indicates that diffusion alone would result in lower GEM levels in the top snow levels at night due to fast equilibration with ambient air (even in cases of low snow diffusivity). This diffusion model did not even account for additional mixing mechanisms in snowpack such as advection and convection; consequently it would give a low limit of the gas transport rate inside the snowpack. The modeling results suggest that additional nighttime sources of GEM may be present, and we propose that further studies should focus on nighttime GEM production mechanisms.

To further evaluate the role of environmental parameters, particularly solar radiation, in controlling GEM production in surface snow layers, we investigated in detail a 20-day period in late winter (from DOY 82 to 102). Figure 4 compares GEM in ambient air (at the $245 \mathrm{~cm}$ inlet, or $\sim 80 \mathrm{~cm}$ above the snow surface at this time) within the uppermost sampling layer in the snowpack $(0-30 \mathrm{~cm}$ depth interval). The total snowpack depth was initially stable at $\sim 145 \mathrm{~cm}$ from DOY 82 to 85 , but increased to $\sim 160 \mathrm{~cm}$ from DOY 86 to 88 as a precipitation event occurred during these days. The snowpack depth then remained stable (i.e., $163 \pm 4 \mathrm{~cm}$ ) until DOY 102. Consequently, the inlet sampling the $0-30 \mathrm{~cm}$ depth interval changed from the $120 \mathrm{~cm}$ to the $150 \mathrm{~cm}$ height above ground inlet, which resulted in the sampling depth decreasing from $\sim 25 \mathrm{~cm}$ to $\sim 10 \mathrm{~cm}$ depth from DOY 86 to 88 (Fig. 4 , dashed line). Figure 4 also shows wind speed, incoming solar radiation, precipitation amount, and snow temperature.

GEM concentrations in the snow exhibited a diel pattern, with maxima as high as $8 \mathrm{ng} \mathrm{m}^{-3}$, which generally occurred about $1 \mathrm{~h}$ after the solar irradiation maximum. While GEM in the top snowpack layer was above atmospheric values during most times, including at night, during two nights (DOY 83 and 90) GEM levels dropped to slightly below ambient air levels. The periods of lowest early-morning GEM levels corresponded to periods with high wind speeds. Highest nighttime GEM levels where related to periods with low winds (e.g., DOY 86, 93, or 95). We conclude that high wind speeds lead to an increase of the mixing of snowpack air GEM with air having lower atmospheric levels from above the snow surface. Consequently, in addition to chemical formation and destruction, and diffusive transport driven by snow physical parameters (e.g., porosity and tortuosity; Eq. 1), advection from wind pumping influences snowpack GEM levels. Seok et al. (2009) showed that neglecting wind pumping resulted in considerable underestimation of $\mathrm{CO}_{2}$ fluxes (i.e., $36 \%$ ). The fact that GEM in surface snow even dropped below ambient air GEM levels during two occasions with high winds (DOY 83 and 90 with wind speeds above $5 \mathrm{~m} \mathrm{~s}^{-1}$ ) can possibly be attributed to the mixing with deeper snowpack air that is depleted in GEM. The fact that the lowest GEM was observed on DOY 83 when the sampling inlet was located deeper - i.e., $25 \mathrm{~cm}$ depth - supports this conclusion.

Figure 4 further shows that on three days (DOY 86, 91 and 94) GEM in the $0-30 \mathrm{~cm}$ layer increased to even more elevated levels, and that these increases coincided with or occurred shortly after fresh snowfall events. A recent study at Sagehen Basin, a high-elevation watershed in the Sierra 


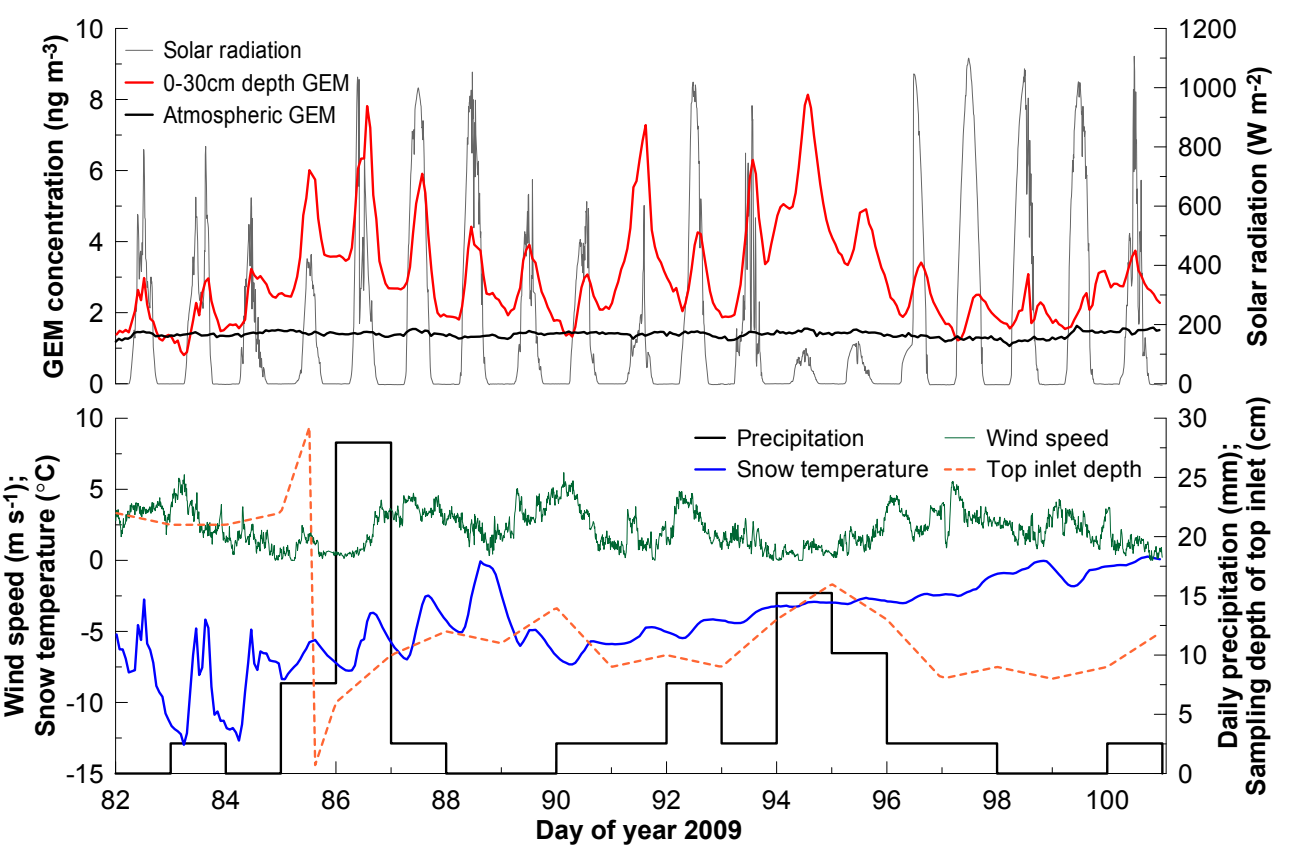

Fig. 4. GEM concentration in the snow interstitial air measured in the 0-30 cm depth top snow layer from day of year 82 to 102 (red line). During this period, the depth of this inlet decreased from $\sim 22 \mathrm{~cm}$ to $\sim 13 \mathrm{~cm}$ (dashed orange line). Atmospheric GEM (thick black line) was stable with an average value of $1.4 \pm 0.1 \mathrm{ng} \mathrm{m}^{-3}$. Wind speed (green line), solar radiation (gray line), and daily precipitation (black histogram) collected at the Soddie SNOTEL station are also reported.

Nevada mountains in California, showed that wet deposition (precipitating snow) was the major $\mathrm{Hg}$ deposition pathway during winter (Faïn et al., 2011). The NWT data suggest that fresh snow provides a new reservoir of photoreducible $\mathrm{Hg}(\mathrm{II})$ and that highest surface snow GEM levels are hence linked to the deposition of new snow. Notably, these elevated GEM levels occurred during periods with relatively low solar radiation (as snowfall was related to cloudy conditions), further suggesting that photochemical production of GEM is not radiation-limited at this site. The GEM concentration in the upper snow layer correlates nicely with the precipitation amount observed the same day or on the previous day (Fig. 5). This correlation is progressively lower with increasing number of days after the precipitation occurred, and is finally lost four days after a precipitation event as shown in the regressions that analyze the daytime GEM levels in the 0-30 cm depth layer in response to fresh snowfall. A similar analysis was conducted on measurements collected during winter 2011/2012. This 2011/2012 data record overall spans a longer time period, i.e., from earlier to later in the snow cover season. However, due to instrument problems and a different experimental protocol, this record has fewer snow precipitation events for consideration. Nonetheless, results show similar tendencies - i.e., elevated SIA GEM levels during and immediately following snowfall events - and consequently confirm the findings drawn from the year 2009 data.

These results can be related to previous work conducted by Lalonde et al. (2003) at a mid-latitude Canadian site, which showed a $40 \%$ loss of $\mathrm{THg}$ concentrations in the surface snow within $24 \mathrm{~h}$ of its deposition. Our data show that reemission patterns occurred in the top NWT snowpack, confirming the importance to consider photo-induced reduction of $\mathrm{Hg}(\mathrm{II})$ in snow and subsequent volatilization in watershed mass balance studies.

\subsection{Low GEM levels in the deep snowpack}

Figures 1 to 3 show that GEM levels decreased with increasing depth and the consistent occurrence of below-ambient GEM concentrations with levels as low as $0.1 \mathrm{ng} \mathrm{m}^{-3}$ between DOY 40 and 60 at the lowest inlet, located $10 \mathrm{~cm}$ above the snow-soil interface. These patterns illustrate that there must have been a sink for GEM in the deep layers of the snowpack throughout the entire measurement campaign. GEM concentration gradients average about $0.02 \mathrm{ng} \mathrm{m}^{-3} \mathrm{~cm}^{-1}$ in the upper snow layers and become smaller in the deepest snow layers. The GEM gradients imply a vertical transport of GEM from the snowpack layer with its maximum concentration to snowpack layers where concentrations are lowest. Further indication of vertical GEM transport is the temporal delay of peak diurnal GEM concentrations and the decreasing magnitudes of diel patterns with increasing depth. At $135 \mathrm{~cm}$ below the snow surface, where GEM concentrations averaged about $0.4 \mathrm{ng} \mathrm{m}^{-3}$, diel variability was no longer evident. 


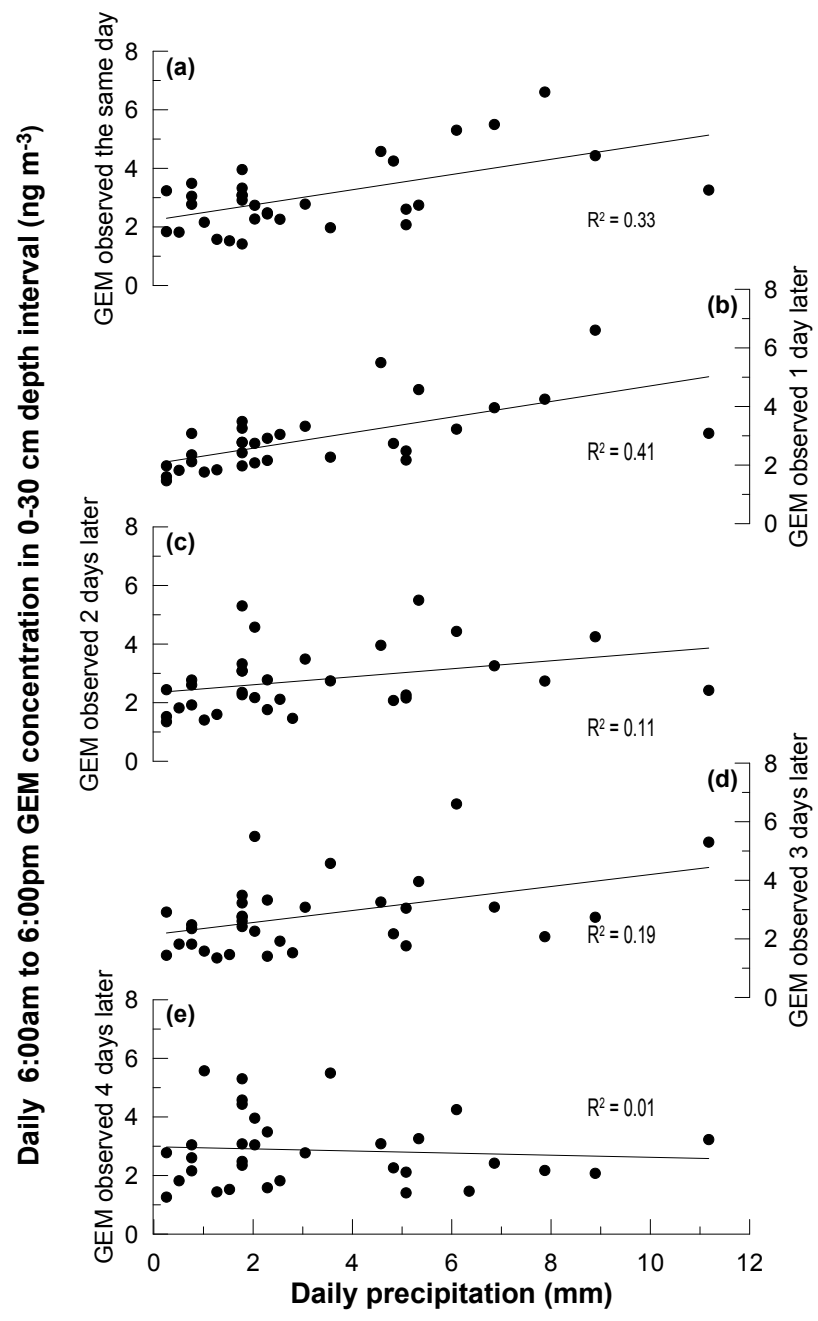

Fig. 5. GEM concentration observed in the upper snowpack layer (0-30 cm depth) from 6.00 a.m. to 6.00 p.m. and averaged daily, as a function of the daily amount of precipitation (in liquid water equivalents). GEM observed the same day (a), a day after (b), two days after (c), three days after (d), and four days after (e). Data from the entire 2009 measurement campaign (i.e., from DOY 37 to 128) are plotted.

There are several possible processes that might drive the GEM depletion in the deeper snowpack. Adsorption of GEM onto ice surfaces could be a possibility; however BartelsRausch et al. (2008) showed that this process is weak at environmental temperatures. These authors reported an adsorption enthalpy of $-28 \pm 2 \mathrm{~kJ} \mathrm{~mol}^{-1}$ and an adsorption equilibrium constant $K$ of $\sim 10^{-4} \mathrm{~cm}$ extrapolated to $270 \mathrm{~K}$. Such a low value of this constant reflects a negligible partitioning of GEM with snow or ice for the environmental temperature experienced at the Soddie site. Hence, the low GEM levels in the lower snowpack are evidence for a chemical, physical, or biological sink for GEM located in the snowpack or in the soils underlying the snowpack.
In order to assess if this GEM sink was driven by processes in the lower snowpack layers or by processes occurring in the soil underneath the snow, we investigated in detail the vertical evolution of GEM flux in the snowpack. If soil processes were a determining sink, then GEM fluxes through the snow layers above the soil interface would be expected to be constant with height. Consequently, we hypothesize that a constant GEM flux through the snowpack would indicate that the snowpack itself is rather inert and that decreasing GEM levels at lower levels are mainly driven by GEM depletion occurring in the underlying soil. Conversely, a decreasing GEM flux from the surface to the bottom of the snowpack would be indicative of a GEM removal mechanism that is located within the snowpack.

GEM vertical concentration gradients from the multiple inlet measurements allow for calculation of vertical diffusive GEM fluxes through the snowpack using Fick's first law. This approach has been previously applied for $\mathrm{CO}_{2}$, ozone, and $\mathrm{NO}_{\mathrm{x}}$ at NWT, and its limitations have been discussed in detail by Seok et al. (2009). The following Fick's law equation was applied here to calculate GEM fluxes for various depths:

$F_{\mathrm{GEM}}=-\varphi \tau D_{\mathrm{GEM}} \frac{P_{0}}{P}\left(\frac{T}{T_{0}}\right)^{\alpha}\left(\frac{\partial C_{\mathrm{GEM}}}{\partial z}\right)$,

where $T_{0}=273.15 \mathrm{~K}, P_{0}=1013.25 \mathrm{mbar}$ (STP), $T$ and $P$ are values of temperature and pressure in the snowpack, $\varphi$ is the snow porosity, $\tau$ is the snow porosity, and $D_{\mathrm{GEM}}$ the GEM diffusion coefficient at STP. It is important to note that the gradient flux approach (Seok et al., 2009) based on Eq. (1) contains approximations, notably due to its 1-D structure which does not accurately represent the spatial heterogeneities of snowpack. In addition, uncertainties on snow physics parameters such as porosity or tortuosity affect flux calculations. Another potential complication in this diffusion flux calculation was the presence of crust and ice layers, which may constitute diffusion barriers which are not considered in the Fick's law calculation (Eq. 1). Snow density profiles were measured weekly in an adjacent open meadow area $\sim 30 \mathrm{~m}$ away from the gas sampling site with similar vegetation and slope characteristics. These profiles revealed no ice layers before 30 March 2009, and few ice lenses during April and May at depths $\sim 50 \mathrm{~cm}$ below the snow surface. However, our sampling technique is rather robust against the influence of ice lenses and crusts (Seok et al., 2009). Ice lenses do not span over an infinitely large area; thus gases diffusing through the snowpack would continue to travel around the ice lenses and crusts, and gas concentration at each arbitrary horizontal layer in the snowpack would equilibrate and maintain a distinct concentration gradient.

An elegant way to investigate the changes in GEM fluxes with depth is to normalize GEM gradients to the measured gradients of $\mathrm{CO}_{2} \cdot \mathrm{CO}_{2}$ is exclusively released by wintertime respiration processes in the soil underneath the snow (Liptzin et al., 2009). Assuming a constant $\mathrm{CO}_{2}$ source at the 


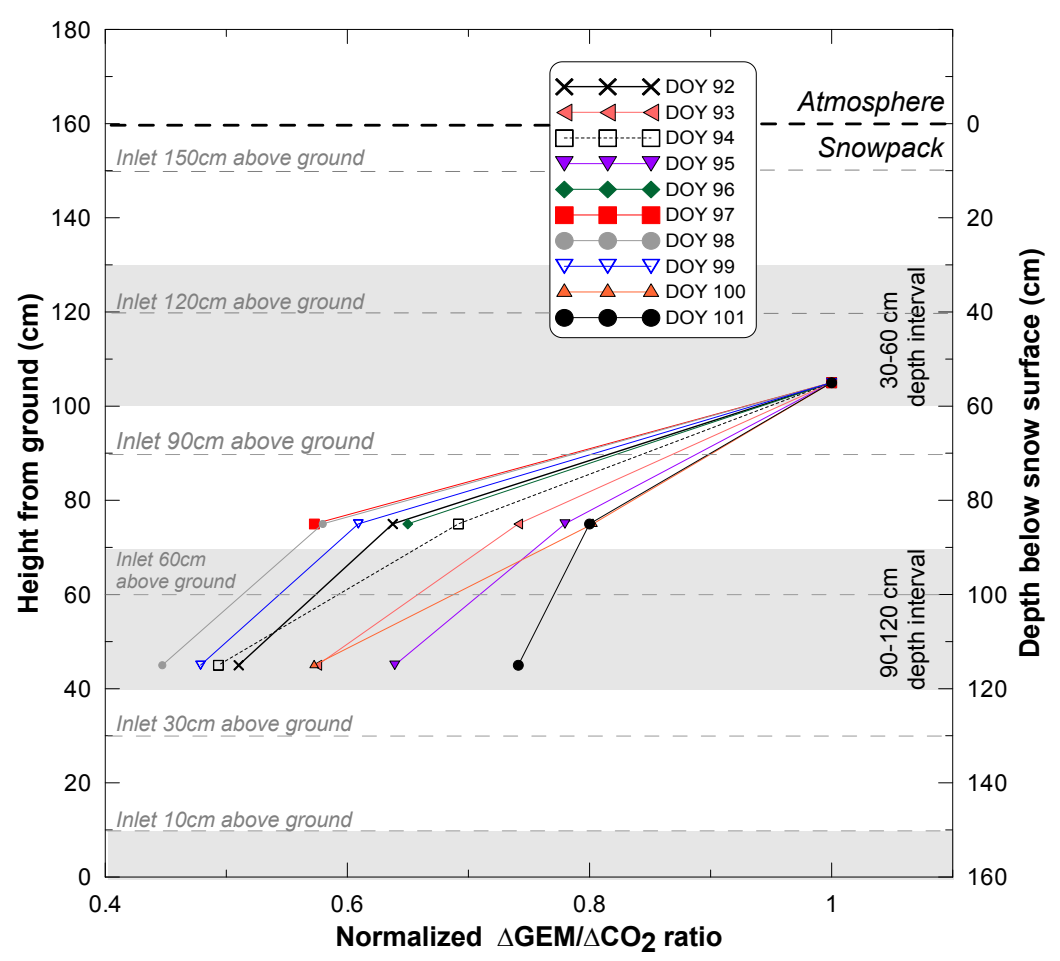

Fig. 6. Evolution with depth of daily $\triangle \mathrm{GEM} / \Delta \mathrm{CO}_{2}$ ratio calculated over three inlet intervals: $120-90 \mathrm{~cm}$ above ground (i.e, representative of 30-60 cm layer below snow surface), $90-60 \mathrm{~cm}$ above ground (i.e, representative of 60-90 cm layer below snow surface), $60-30 \mathrm{~cm}$ above ground (i.e, representative of 90-120 cm layer below snow surface) for 10 days (labeled by day of year (DOY)). All ratio values have been normalized to the ratio observed in the top 30-60 cm layer below the snow surface. Data were collected in 2009.

bottom of the snowpack, changes in $\mathrm{CO}_{2}$ snowpack gradients are driven by changes in snow physics and wind-induced ventilation. These processes would affect GEM fluxes in the same way; thus the GEM $/ \mathrm{CO}_{2}$ flux ratio will effectively cancel out most uncertainties in the snowpack flux calculation. The GEM $/ \mathrm{CO}_{2}$ flux ratio, as defined in equation (2), is directly related to measured $\Delta \mathrm{GEM}$ and $\Delta \mathrm{CO}_{2}$, the gradients in GEM and $\mathrm{CO}_{2}$ concentrations observed between two defined depths:

$$
\frac{F_{\mathrm{GEM}}}{F_{\mathrm{CO}_{2}}}=\frac{D_{\mathrm{GEM}}}{D_{\mathrm{CO}_{2}}} \times \frac{\Delta_{\mathrm{GEM}}}{\Delta_{\mathrm{CO}_{2}}},
$$

with $\mathrm{D}$ reflecting the diffusivity of both gases, and the ratio of $\mathrm{D}_{\mathrm{GEM}} / \mathrm{D}_{\mathrm{CO}_{2}}$ expected to be constant. Changes in the ratio defined in Eq. (2) with snowpack depth should be constant if changes in GEM and $\mathrm{CO}_{2}$ are both driven by snow physics or wind-induced ventilation; if ratios change with depth, this would be indicative of GEM chemical sinks (or sources) within the snowpack. Figure 6 shows daily averaged $\Delta \mathrm{GEM} / \triangle \mathrm{CO}_{2}$ ratios calculated for three different depth gradients: inlets 120 to $90 \mathrm{~cm}, 90$ to $60 \mathrm{~cm}$, and 60 to $30 \mathrm{~cm}$, calculated for a 10-day period (DOY 92-102). Note that values reported in Fig. 6 have been all normalized to the ratios observed in the top 30-60 cm layer below the snow surface (also note that non-normalized ratios are all negative due to the different concentration gradients and fluxes for $\mathrm{CO}_{2}$ and
GEM; normalized $\Delta \mathrm{GEM} / \triangle \mathrm{CO}_{2}$ ratio values are positive). During this time, the $120 \mathrm{~cm}$ inlet was about $40 \mathrm{~cm}$ deep. Consequently, the photolytic zone was above the uppermost depth interval considered in this analysis. Soil moisture was constant during this time interval, and thus a relatively constant flux of $\mathrm{CO}_{2}$ from the soil would be expected during these conditions (Liptzin et al., 2009).

Figure 6 shows clear decreases of the GEM / $\mathrm{CO}_{2}$ flux ratio with depth for all observation days. This pattern is a strong indication that GEM fluxes through the snowpack are not constant with height, and that GEM produced in the upper layer of the snowpack is destroyed within the lower snowpack as it diffuses to lower snowpack depth.

To our knowledge, this analysis shows for the first time evidence of light-independent (dark) destruction of GEM in a mid-latitude snowpack, a process which previously has only been observed in polar snow (Dommergue et al., 2003b; Ferrari et al., 2004a; Faïn et al., 2008; Dommergue et al., 2012). With more than 70 days of observations (Fig. 3) in a midlatitude snowpack, the NWT study demonstrates that this GEM chemistry is more universal and persistent than previously thought.

The GEM loss observed in the SIA of the NWT snowpack must involve a chemical, physical, or biological sink within the snow. Oxidants leading to GEM destruction in 

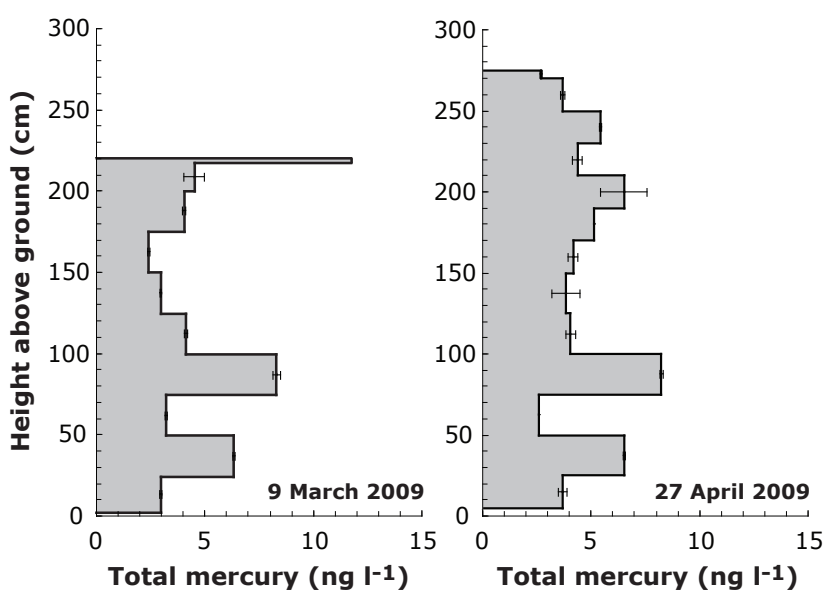

Fig. 7. Snow depth profiles of $\mathrm{THg}$ in snow collected in the vicinity of the gradient tower in an open area. Every sample was measured three times and error bars (which are too small in some cases to be readable) indicate corresponding standard deviations.

the snowpack are not yet clearly identified. At Summit in Greenland, Faïn et al. (2008) observed a complete depletion of GEM at $200 \mathrm{~cm}$ depth during early June, and the authors suggested that the snowpack may act as a dark source of $\mathrm{Br}_{2}$ which subsequently oxidizes GEM. This mechanism involves dark oxidation of $\mathrm{Br}^{-}$ions by ozone at the surface of the snow crystals as observed by Oum et al. (1998) during laboratory measurements. But it is unclear to what degree bromine species play a role in interior continental snowpacks. Ozone is another potential oxidant for GEM, and a wide range of rate constants for the reaction of gas-phase $\mathrm{Hg}$ with ozone are reported in the literature. However, it is very unlikely that oxidation of GEM by $\mathrm{O}_{3}$ proceeds via homogeneous gas-phase reaction; heterogeneous reactions on surfaces are required to induce the collisions necessary to enhance the rate of this reaction by making the formation of the intermediates and products more favorable (Subir et al., 2011). Such heterogeneous reaction conditions may well exist in snowpacks. Ozone in the Niwot Ridge snowpack declines at a fast rate with depth, resulting in less than $10 \%$ of ozone remaining $\sim 50 \mathrm{~cm}$ below the surface (see ozone data in Helmig et al., 2009, and in Bocquet et al., 2007); similar ozone gradients were again observed during this campaign (data not shown). If ozone was the main GEM oxidant, then the upper snowpack layers would exhibit the strongest GEM sink, and GEM loss from ozone would be lower in the deeper snow. Further, the relatively consistent ozone gradients would not be able to explain the highly dynamic patterns of GEM in the lower snowpack.

$\mathrm{NO}_{\mathrm{x}}$ concentrations were measured at the Soddie site during winter 2007 using the same snowtower sampling setup (Helmig et al., 2009). These data show an upward flux of NO from the soil through the snowpack, implying that biogeochemical processes in the subnival soil are the dominant
NO source (Helmig et al., 2009). While diffusing upward, a portion of $\mathrm{NO}$ is converted to $\mathrm{NO}_{2}$, with ozone being one likely reactant. Interestingly, enhanced $\mathrm{NO}$ concentrations in the SIA are co-located with GEM-depleted depths. Previous studies have demonstrated that $\mathrm{NO}_{2}$ is not a potential oxidant for GEM in gas phase (Hall et al., 1995). However, destruction of GEM was recently observed at Concordia Station, Antarctica, both in SIA and $20 \mathrm{~cm}$ above the snow surface when $\mathrm{NO}_{\mathrm{x}}$ emissions from the upper photolytic snow layers peaked in late afternoon (Dommergue, personal communication, 2012). Although not understood yet and still speculative, these observations suggest taking a closer look at chemical interaction between GEM and NO.

Another interesting aspect of these data is that we did not observe complete GEM depletion as previously reported from SIA measurements at polar latitudes, either above perennial firn in Greenland or Antarctica (Faïn et al., 2008; Dommergue et al., 2012), or above frozen coastal soils at polar latitudes (Ferrari et al., 2004a). At NWT, GEM generally remained close to or above $0.4 \mathrm{ng} \mathrm{m}^{-3}$ in the deepest snow layers, similarly to observations reported during a 4-day study at the sub-Arctic location of Kuujjuarapik (Dommergue et al., 2003b). One possible reason for this could be a contribution of GEM emitted from the underlying soils as found by Nelson et al. (2008), who detected upward mobility of isotopically labeled $\mathrm{Hg}$ from soils into overlying snow.

Snowpack temperature is notably different between the NWT snowpack and the polar locations. At NWT, the temperature of the deep snow layer and the soil underneath the snowpack remained relatively stable and close to $0^{\circ} \mathrm{C}$ during the entire campaign. Such warmer conditions favor disturbed surface for snow grains where geometric constraints and elevated levels of impurities can stabilize liquids in reservoirs, even below the eutectic temperature (Nye, 1991; Bartels- Rausch et al., 2012). Consequently, multiphase gasliquid chemistry could be more important in the warmer NWT snowpack compared to glacial ice caps. It is possible that multiphase chemistry promotes GEM oxidation with faster rates of reaction. In addition to more-favorable aqueous chemistry, a small amount of liquid water in the snowpack may also favor the presence of biological processes. The warm NWT snowpack notably supports bacterial, algal, and fungal communities which potentially affect trace gas chemistry (Williams et al., 2009, and references therein). Interestingly, warm soil temperatures also result in a large thermal gradient at NWT, and a vertical gradient in diurnal growth and shrinking of the liquid water, causing disturbed interface around snow grains. A recent study showed that a freezing acidic solution containing nitrite $(250 \mu \mathrm{M})$ or hydrogen peroxide $(2.2 \mu \mathrm{M})$ can oxidize dissolved elemental mercury in the dark (O'Concubhair et al., 2012). These authors report laboratory evidence of freeze-induced reaction of dissolved gaseous mercury to form $\mathrm{Hg}$ (II) species. Such freezing conditions could exist almost daily in a mid-latitude 
snowpack given its diurnal cycle of top-bottom thermal gradients.

Although we report for the first time dark oxidation of GEM in a mid-latitude snowpack, there is still a lack of understanding about the GEM oxidation processes observed above and inside the snowpack, and the mechanisms involved within the NWT snowpack remain unclear. More detailed laboratory kinetic studies of GEM oxidation using ice/snow surfaces are thus highly warranted.

\subsection{Does GEM oxidation increase the $\mathrm{Hg}$ pool stored in snowpacks?}

The patterns of GEM dynamics in the NWT snowpack indicate that part of the divalent $\mathrm{Hg}$ (II) species deposited to the surface of the snowpack are reduced to GEM, which then is transported both upwards to the atmosphere and downward in the snowpack, where it subsequently is oxidized and potentially stored in snowpack as divalent $\mathrm{Hg}(\mathrm{II})$. One key question is thus whether these chemical processes and vertical transport processes affect $\mathrm{Hg}$ concentrations of total $\mathrm{Hg}$ species in the snowpack. To address this question, two snow pits were sampled at the beginning and at the end of the measurement period, on 9 March and 27 April, respectively, for total $\mathrm{Hg}$ (THg) determination (Fig. 7). Using snow density profiles carried out in these two pits, we estimate total $\mathrm{Hg}$ loads of the snowpack at $4.0 \mu \mathrm{g} \mathrm{m}^{-2}$ in early March, and at $5.8 \mu \mathrm{g} \mathrm{m}^{-2}$ in late April.

Figure 7 shows depth patterns of $\mathrm{THg}$ for the different snow pits. In general, snow $\mathrm{Hg}$ concentrations did not show the depth profile that would be expected based on GEM concentration gradients and diffusion processes; for example, surface snow layers were expected to be depleted in $\mathrm{THg}$ due to photoreduction and subsequent losses as GEM, while deeper snow layers are expected to be enriched in $\mathrm{THg}$ due to oxidation of GEM and deposition in snowpack as divalent $\mathrm{Hg}$ (II). However, the lack of a vertical signal in $\mathrm{THg}$ distribution can be explained by a simple calculation. The GEM gradient flux calculations above indicated a flux of approximately $0.05 \mathrm{ng} \mathrm{m}^{-2} \mathrm{~h}^{-1}$ propagating downward from the upper snow layer (averaged value over the entire campaign), decreasing to lower values deeper in the snowpack. Assuming that the entire GEM flux difference is converted and stored as divalent $\mathrm{Hg}$ species in deeper snow layers, we would expect an increase of $\sim 60 \mathrm{ng} \mathrm{m}^{-2}$ of $\mathrm{Hg}$ to the snowpack load between 9 March and 27 April. Total snowpack THg loads calculated using snow pits on 27 April and 9 March showed a total snowpack $\mathrm{Hg}$ load of $4.0 \mu \mathrm{g} \mathrm{m}^{-2}$ and $5.8 \mu \mathrm{g} \mathrm{m}^{-2}$. The mass of vertically redistributed GEM due to dark oxidation in lower layers hence is $\sim$ two orders of magnitude smaller compared to the total snowpack Hg loads.

\section{Conclusions}

Gaseous elemental mercury concentrations in the interstitial air in the deep, seasonal, mid-latitude Rocky Mountain alpine snowpack exhibited a highly dynamic cycling. The GEM patterns observed at NWT were complex, involving both production and destruction of GEM within the snowpack, and transport processes such as diffusion, and advection-driven transport.

Near the snow-air interface, GEM showed distinct diurnal cycles with concentration maxima observed during midday that were associated with solar irradiance. During lowwind periods, GEM in surface snow layers remained significantly above ambient air levels not just during daytime but also at night, which may indicate potential GEM production overnight. Further studies should focus on evaluating the mechanisms involved in nighttime GEM production. Interestingly, the highest GEM surface production and reemission occurred after fresh snowfall and possible wet deposition of photoreducible mercury to the snowpack. These results confirm the importance of photo-induced reduction of $\mathrm{Hg}(\mathrm{II})$ in snow and subsequent volatilization. This is the first study to actually show that photochemical GEM production occurs throughout the entire winter and thereby supports the notion that snowpacks effectively reduce the effects of atmospheric mercury deposition to watersheds due to reemission fluxes prior to snowmelt.

In the deep layers of the NWT snowpack, concentrations were consistently below those found in ambient air, independent of daytime or nighttime. At the lowest levels (from $120 \mathrm{~cm}$ depth to the snow-soil interface), GEM was found to be rather constant $\left(\sim 0.4 \mathrm{ng} \mathrm{m}^{-3}\right.$ during almost the entire campaign). A vertical analysis of GEM / $\mathrm{CO}_{2}$ flux ratios indicated that GEM destruction occurred in the deeper snowpack layers. The chemical or biological mechanisms involved in this destruction remain unclear, and detailed kinetic studies of multiphasic GEM oxidation using snow and ice surfaces are warranted to improve our understanding of such field observations. Specific experiments could also be helpful in linking photochemical cycles of $\mathrm{Hg}$ and other compounds (e.g., $\mathrm{NO}_{\mathrm{x}}$ ) that have been observed at elevated concentrations within the snowpack.

Observations of photolytic GEM production in surface snow and GEM destruction in deeper snow layer led us to investigate the possibility of a net transfer of mercury from upper to lower snow layers in the NWT snowpack. Our study shows that transport processes and redox reactions within the lower snowpack, however, are likely too small to drive significant vertical redistribution of total $\mathrm{Hg}$ in the snowpack. However, further studies should quantify not only total $\mathrm{Hg}$ but various forms of soluble, $\mathrm{Hg}$-bound (PHg), and bioavailable $\mathrm{Hg}$ to assess the importance of such vertical redistribution. While soluble mercury could be reduced more easily, PHg may accumulate in snowpacks and not be subject to photo-reduction and transport. 
Acknowledgements. This work was supported by the Research Advisory Council and by an Internal Project Assignment of the Desert Research Institute, and by NSF grant OPP-0713943. Research at Niwot Ridge was funded by the Long-Term Ecological Research grant from the National Science Foundation (award \# NSF DEB-9211776). We thank K. Chowanski for assistance with field operation, R. Gallegos for conducting the 2011-2012 measurements and data reduction, B. Seok for help with the data analyses, and A. Pierce for analyzing snow samples for $\mathrm{THg}$ concentration. Any opinions, findings, and conclusions expressed in this material are those of the authors and do not necessarily reflect the views of the National Science Foundation.

Edited by: M. Bahn

\section{References}

Bartels-Rausch, T., Jacobi, H.-W., Kahan, T. F., Thomas, J. L., Thomson, E. S., Abbatt, J. P. D., Ammann, M., Blackford, J. R., Bluhm, H., Boxe, C., Domine, F., Frey, M. M., Gladich, I., Guzmán, M. I., Heger, D., Huthwelker, Th., Klán, P., Kuhs, W. F., Kuo, M. H., Maus, S., Moussa, S. G., McNeill, V. F., Newberg, J. T., Pettersson, J. B. C., Roeselová, M., and Sodeau, J. R.: Relationship between snow microstructure and physical and chemical processes, Atmos. Chem. Phys. Discuss., 12, 30409 30541, doi:10.5194/acpd-12-30409-2012, 2012.

Bartels-Rausch, T., Huthwelker, T., Jori, M., Gaggler, H. W., and Ammann, M.: Interaction of gaseous elemental mercury with snow surfaces: laboratory investigation, Environ. Res. Lett., 3, 045009, doi:10.1088/1748-9326/3/4/045009, 2008.

Bartels-Rausch, T., Krysztofiak, G., Bernhard, A., Schlaeppi, M., Schwikowski, M., and Ammann, M.: Photoinduced reduction of divalent mercury in ice by organic matter, Chemosphere, 82 , 199-203, doi:10.1016/j.chemosphere.2010.10.020, 2011.

Bocquet, F., Helmig, D., and Oltmans, S. J.: Ozone in interstitial air of the mid-latitude, seasonal snowpack at Niwot Ridge, Antarctic and Alpine Research, 39, 375-387 2007.

Caine, N.: Snowpack influences on geomorphic processes in Green Lakes Valley, Colorado Front Range, Geog. J., 161, 55-68, 1995.

Dominé, F. and Shepson, P. B.: Air-Snow Interactions and Atmospheric Chemistry, Science, 297, 1506-1510, 2002.

Dommergue, A., Ferrari, C. P., Gauchard, P.-A., Boutron, C. F., Poissant, L., Pilote, M., Adams, F., and Jitaru, P.: The fate of mercury species in a sub-arctic snowpack during snowmelt, Geophys. Res. Lett., 30, 1621, doi:10.1029/2003GL017308, 2003 a.

Dommergue, A., Ferrari, C. P., Poissant, L., Gauchard, P.-A., and Boutron, C. F.: Diurnal cycles of gaseous mercury within the snowpack at Kuujjuarapik/Whapmagoostui, Québec, Canada, Environ. Sci. Technol., 37, 3289-3297, 2003b.

Dommergue, A., Balhmann, E., Ebinghaus, R., Ferrari, C., and Boutron, C.: Laboratory simulation of $\mathrm{Hg}^{\circ}$ emissions from a snowpack, Anal. Bioanal. Chem., 288, 319-327, doi:10.1007/s00216-007-1186-2, 2007.

Dommergue, A., Barret, M., Courteaud, J., Cristofanelli, P., Ferrari, C. P., and Gallée, H.: Dynamic recycling of gaseous elemental mercury in the boundary layer of the Antarctic Plateau, Atmos. Chem. Phys., 12, 11027-11036, doi:10.5194/acp-1211027-2012, 2012
Douglas, T. A., Loseto, L. L., Macdonald, R. W., Outridge, P. M., Dommergue, A., Poulain, A., Amyot, M., Barkay, T., Berg, T., Chételat, J., Constant, P., Evans, M., Ferrari, C., Gantner, N., Johnson, M. S., Kirk, J. L., Kroer, N., Larose, C., Lean, D., Nielsen, T. G., Poissant, L., Rognerud, S., Skov, H., Sørensen, S., Wang, F., and Wilson, S.: The fate of mercury in Arctic terrestrial and aquatic ecosystems, a review, Environ. Chem., 321, doi:org/10.1071/EN11140, 2012.

Durnford, D. and Dastoor, A.: The behavior of mercury in the cryosphere: A review of what we know from observations, J. Geophys. Res., 116, D06305, doi:10.1029/2010jd014809, 2011.

Ebinghaus, R., Jennings, S. G., Schroeder, W. H., Berg, T., Donaghy, T., Guentzel, J., Kenny, C., Kock, H. H., Kvietkus, K. Landing, W., Muhleck, T., Munthe, J., Prestbo, E. M., Schneeberger, D., Slemr, F., Sommar, J., Urba, A., Wallschlager, D., and Xiao, Z.: International field intercomparison measurements of atmospheric mercury species at Mace Head, Ireland, Atmos. Environ., 33, 3063-3073, 1999.

Ericksen, J. A., Gustin, M. S., Lindberg, S. E., Olund, S. D., and Krabbenhoft, D. P.: Assessing the potential for re-emission of mercury deposited in precipitation from arid soils using a stable isotope, Environ. Sci. Technol., 39, 8001-8007, 2005.

Erickson, T. A.: Development and application of geostatistical methods to modeling spatial variation in snowpack properties, Front Range, Colorado, University of Colorado at Boulder, Boulder, p 190, 2004.

Faïn, X., Grangeon, S., Balhmann, E., Fritsche, J., Obrist, D., Dommergue, A., Ferrari, C., Cairns, W., Ebinghaus, R., Barbante, C., Cescon, P., and Boutron, C.: Diurnal production of Gaseous Mercury in the alpine snowpack before snowmelt, J. Geophys. Res.Atmos., 112, D21311, doi:10.1029/2007JD008520, 2007.

Faïn, X., Ferrari, C. P., Dommergue, A., Albert, M., Battle, M., Arnaud, L., Barnola, J.-M., Cairns, W., Barbante, C., and Boutron, C.: Mercury in the snow and firn at Summit Station, Central Greenland, and implications for the study of past atmospheric mercury levels, Atmos. Chem. Phys., 8, 3441-3457, doi:10.5194/acp-8-3441-2008, 2008.

Faïn, X., Obrist, D., Hallar, A. G., Mccubbin, I., and Rahn, T.: High levels of reactive gaseous mercury observed at a high elevation research laboratory in the Rocky Mountains, Atmos. Chem. Phys., 9, 8049-8060, doi:10.5194/acp-9-8049-2009, 2009.

Faïn, X., Obrist, D., Barth, C., Ashley, P., Gustin, M., and Boyle, D.: Whole-watershed mercury balance at Sagehen Creek, Sierra Nevada, CA, Geochim. Cosmochim. Acta, 75, 2379-2392, doi:10.1016/j.gca.2011.01.041, 2011.

Ferrari, C. P., Dommergue, A., and Boutron, C. F.: Profiles of Mercury in the snow pack at Station Nord, Greenland shortly after polar sunrise, Geophys. Res. Lett., 31, L03401, doi:10.1029/2003GL018961, 2004a.

Ferrari, C. P., Dommergue, A., Skov, H., Goodsite, M., and Boutron, C. F.: Nighttime production of elemental gaseous mercury in interstitial air of snow at Station Nord, Greenland, Atmos. Environ., 38, 2727-2735, 2004b.

Fisher, J. A., Jacob, D. J., Soerensen, A. L., Amos, H. M., Steffen, A., and Sunderland, E. M.: Riverine source of Arctic Ocean mercury inferred from atmospheric observations, Nat. Geosci., 5, 499-504, doi:10.1038/ngeo1478, 2012.

Fitzgerald, W. F., Engstrom, D. R., Mason, R. P., and Nater, E. A.: The case for atmospheric mercury contamination in remote ar- 
eas, Environ. Sci. Technol., 32, 1-7, 1998.

Hall, B., Schager, P., and Ljungstrom, E.: An experimentalstudy on the rate of reaction between mercury-vapor and gaseous nitrogen-dioxide, Water Air Soil Pollut., 81, 121-134, doi:10.1007/bf00477260, 1995.

Hedgecock, I. M., Pirrone, N., and Sprovieri, F.: Chasing quicksilver northward: mercury chemistry in the Arctic troposphere, Environ. Chem., 5, 131-134, doi:10.1071/en08001, 2008.

Helmig, D., Seok, B., Williams, M. W., Hueber, J., and Sanford, R.: Fluxes and chemistry of nitrogen oxides in the Niwot Ridge, Colorado, snowpack, Biogeochemistry, 95, 115-130, doi:10.1007/s10533-009-9312-1, 2009.

Hirdman, D., Aspmo, K., Burkhart, J. F., Eckhardt, S., Sodemann, H., and Stohl, A.: Transport of mercury in the Arctic atmosphere: Evidence for a springtime net sink and summer-time source, Geophys. Res. Lett., 36, L12814, doi:10.1029/2009GL038345, 2009.

Johnson, K. P., Blum, J. D., Keeler, G. J., and Douglas, T. A.: Investigation of the deposition and emission of mercury in arctic snow during an atmospheric mercury depletion event, J. Geophys. Res., 113, D17304, doi:10.1029/2008JD009893, 2008.

Kirk, J. L., St Louis, V. L., and Sharp, M. J.: Rapid reduction and reemission of mercury deposited into snowpacks during atmospheric mercury depletion events at Churchill, Manitoba, Canada, Environ. Sci. Technol., 40, 7590-7596, 2006.

Kuss, J., Zuelicke, C., Pohl, C., and Schneider, B.: Atlantic mercury emission determined from continuous analysis of the elemental mercury sea-air concentration difference within transects between 50 degrees $\mathrm{N}$ and 50 degrees S, Global Biogeochem. Cycles, 25, GB3021, doi:10.1029/2010gb003998, 2011.

Lahoutifard, N., Poissant, L., and Scott, S.: Scavenging of gaseous mercury by acidic snow at Kuujjuarapik, Northern Quebec, Sci. Total Environ., 355, 118-126, 2006.

Lalonde, J. D., Poulain, A. J., and Amyot, M.: The role of mercury redox reactions in snow on snow-to-air mercury transfer, Environ. Sci. Technol., 36, 174-178, 2002.

Lalonde, J. D., Amyot, M., Doyon, M.-R., and Auclair, J.-C.: Photoinduced $\mathrm{Hg}(\mathrm{II})$ reduction in snow from the remote and temperate Experimental Lake Area (Ontario, Canada), J. Geophys. Res., 108, 4200, doi:10.1029/2001JD001534, 2003.

Lindberg, S., Bullock, R., Ebinghaus, R., Engstrom, D., Feng, X. B., Fitzgerald, W., Pirrone, N., Prestbo, E., and Seigneur, C.: A synthesis of progress and uncertainties in attributing the sources of mercury in deposition, Ambio, 36, 19-32, 2007.

Liptzin, D., Williams, M. W., Helmig, D., Seok, B., Filippa, G., Chowanski, K., and Hueber, J.: Process-level controls on $\mathrm{CO}_{2}$ fluxes from a seasonally snow-covered subalpine meadow soil, Niwot Ridge, Colorado, Biogeochemistry, 95, 151-166, doi:10.1007/s10533-009-9303-2, 2009.

Lockhart, L. and Evans M.: Mercury in fish from stock surveys of lakes in the western Northwest Territories: investigations into the factors affecting mercury levels, in: Synopsis of Research Conducted Under the 1999/2000 Northern Contaminants Program, edited by: Kalhok, S., Department of Indian and Northern Affairs, Canada, Vol. R71-19/76-2000E, 189-190, 2000.

Munthe, J., Xiao, Z. F., and Lindqvist, O.: The aqueous reduction of divalent mercury by sulfite, Water Air Soil Pollut., 56, 621-630, 1991.
Nelson, S. J., Johnson, K. B., Weathers, K. C., Loftin, C. S., Fernandez, I. J., Kahl, J. S., and Krabbenhoft, D. P.: A comparison of winter mercury accumulation at forested and no-canopy sites measured with different snow sampling techniques, Appl. Geochem., 23, 384-398, doi:10.1016/j.apgeochem.2007.12.009, 2008.

Nye, J. F.: Thermal-behavior of glacier and laboratory ice, journal of Glaciology, 30421, 401-413, 1991.

O'Concubhair, R., O'Sullivan, D., and Sodeau, J. R.: Dark Oxidation of Dissolved Gaseous Mercury in Polar Ice Mimics, Environ. Sci. Technol., 46, 4829-4836, doi:10.1021/es300309n, 2012.

Oum, K. W., Lakin, M. J., and Finlayson-Pitts, B. J.: Bromine activation in the troposphere by the dark reaction of $\mathrm{O}_{3}$ with seawater ice, Geophys. Res. Lett., 25, 3929-3926, 1998.

Outridge, P. M., Macdonald, R. W., Wang, F., Stern, G. A., and Dastoor, A. P.: A mass balance inventory of mercury in the Arctic Ocean, Environ. Chem., 5, 89-111, 2008.

Poulain, A. J., Lalonde, J. D., Amyot, M., Shead, J. A., Raofie, F., and Ariya, P. A.: Redox transformations of mercury in an Arctic snowpack at springtime, Atmos. Environ., 38, 6763-6774, 2004.

Poulain, A. J., Roy, V., and Amyot, M.: Influence of temperate mixed and deciduous tree covers on $\mathrm{Hg}$ concentrations and photoredox transformations in snow, Geochim. Cosmochim. Acta, 71, 2448-2462, 2007.

Schroeder, W. H., Keeler, G., Kock, H., Roussel, P., Schneeberger, D., and Schaedlich, F.: International field intercomparison of atmospheric mercury measurement methods, Water Air Soil Pollut., 80, 611-620, 1995.

Schroeder, W. H. and Munthe, J.: Atmospheric mercury - An overview, Atmos. Environ., 32, 809-822, 1998.

Selin, N. E., Jacob, D. J., Park, R. J., Yantosca, R. M., Strode, S. A., Jaegle, L., and Jaffe, D.: Chemical cycling and deposition of atmospheric mercury: Global constraints from observations, J. Geophys. Res., 112, D02308, 2007.

Seok, B., Helmig, D., Williams, M. W., Liptzin, D., Chowanski, K., and Hueber, J.: An automated system for continuous measurements of trace gas fluxes through snow: an evaluation of the gas diffusion method at a subalpine forest site, Niwot Ridge, Colorado, Biogeochemistry, 95, 95-113, doi:10.1007/s10533-0099302-3, 2009.

Sommar, J., Wängberg, I., Berg, T., Gøardfeldt, K., Munthe, J., Richter, A., Urba, A., Wittrock, F., and Schroeder, W. H.: Circumpolar transport and air-surface exchange of atmospheric mercury at Ny-Ålesund $\left(79^{\circ} \mathrm{N}\right)$, Svalbard, spring 2002, Atmos. Chem. Phys., 7, 151-166, doi:10.5194/acp-7-151-2007, 2007.

St Louis, V. L., Sharp, M. J., Steffen, A., May, A., Barker, J., Kirk, J. L., Kelly, D. J. A., Arnott, S. E., Keatley, B., and Smol, J. P.: Some sources and sinks of monomethyl and inorganic mercury on Ellesmere island in the Canadian high arctic, Environ. Sci. Technol., 39, 2686-2701, doi:10.1021/es049326o, 2005.

St Louis, V. L., Hintelmann, H., Graydon, J. A., Kirk, J. L., Barker, J., Dimock, B., Sharp, M. J., and Lehnherr, I.: Methylated mercury species in Canadian high arctic marine surface waters and snowpacks, Environ. Sci. Technol., 41, 6433-6441, doi:10.1021/es070692s, 2007.

Steffen, A., Schroeder, W. H., Bottenheim, J., Narayana, J., and Fuentes, J. D.: Atmospheric mercury concentrations: measurements and profiles near snow and ice surfaces in the Cana- 
dian Arctic during Alert 2000, Atmos. Environ., 36, 2653-2661, 2002.

Steffen, A., Schroeder, B., MacDonald, R. W., Poissant, L., and Konoplav, A.: Mercury in the Arctic atmosphere: An analysis of eight years of measurements of GEM at Alert (Canada) and a comparison with observations at Amderma (Russia) and Kuujjuarapik (Canada), Sci. Total Environ., 342, 185-198, 2005.

Steffen, A., Douglas, T., Amyot, M., Ariya, P., Aspmo, K., Berg, T., Bottenheim, J., Brooks, S., Cobbett, F., Dastoor, A., Dommergue, A., Ebinghaus, R., Ferrari, C., Gardfeldt, K., Goodsite, M. E., Lean, D., Poulain, A. J., Scherz, C., Skov, H., Sommar, J., and Temme, C.: A synthesis of atmospheric mercury depletion event chemistry in the atmosphere and snow, Atmos. Chem. Phys., 8, 1445-1482, doi:10.5194/acp-8-1445-2008, 2008.

Subir, M., Ariya, P. A., and Dastoor, A. P.: A review of uncertainties in atmospheric modeling of mercury chemistry I. Uncertainties in existing kinetic parameters - Fundamental limitations and the importance of heterogeneous chemistry, Atmos. Environ., 45, 5664-5676, doi:10.1016/j.atmosenv.2011.04.046, 2011.
Temme, C., Blanchard, P., Steffen, A., Banic, C., Beauchamp, S., Poissant, L., Tordon, R., and Wiens, B.: Trend, seasonal and multivariate analysis study of total gaseous mercury data from the Canadian atmospheric mercury measurement network (CAMNet), Atmos. Environ., 41, 5423-5441, 2007.

Valente, R. J., Shea, C., Humes, K. L., and Tanner, R. L.: Atmospheric mercury in the Great Smoky Mountains compared to regional and global levels, Atmos. Environ., 41, 1861-1873, doi:10.1016/j.atmosenv.2006.10.054, 2007.

Van Loon, L., Mader, E., and Scott, S. L.: Reduction of the aqueous mercuric ion by sulfite: UV spectrum of $\mathrm{HgSO}_{3}$ and its intramolecular redox reaction, J. Phys. Chem. A, 104, 1621-1626, doi:10.1021/jp994268s, 2000.

Williams, M. W., Helmig, D., and Blanken, P.: White on green: under-snow microbial processes and trace gas fluxes through snow, Niwot Ridge, Colorado Front Range, Biogeochemistry, 95, 1-12, doi:10.1007/s10533-009-9330-z, 2009.

Zhang, L. M., Wright, L. P., and Blanchard, P.: A review of current knowledge concerning dry deposition of atmospheric mercury, Atmos. Environ., 43, 5853-5864, doi:10.1016/j.atmosenv.2009.08.019, 2009. 